\title{
The great psychotherapy debate
}

Citation for published version (APA):

Keijsers, G. P. J. (2014). The great psychotherapy debate. Maastricht University. https://doi.org/10.26481/spe.20140425gk

Document status and date:

Published: 25/04/2014

DOI:

10.26481/spe.20140425gk

Document Version:

Publisher's PDF, also known as Version of record

\section{Please check the document version of this publication:}

- A submitted manuscript is the version of the article upon submission and before peer-review. There can be important differences between the submitted version and the official published version of record.

People interested in the research are advised to contact the author for the final version of the publication, or visit the DOI to the publisher's website.

- The final author version and the galley proof are versions of the publication after peer review.

- The final published version features the final layout of the paper including the volume, issue and page numbers.

Link to publication

\footnotetext{
General rights rights.

- You may freely distribute the URL identifying the publication in the public portal. please follow below link for the End User Agreement:

www.umlib.nl/taverne-license

Take down policy

If you believe that this document breaches copyright please contact us at:

repository@maastrichtuniversity.nl

providing details and we will investigate your claim.
}

Copyright and moral rights for the publications made accessible in the public portal are retained by the authors and/or other copyright owners and it is a condition of accessing publications that users recognise and abide by the legal requirements associated with these

- Users may download and print one copy of any publication from the public portal for the purpose of private study or research.

- You may not further distribute the material or use it for any profit-making activity or commercial gain

If the publication is distributed under the terms of Article $25 \mathrm{fa}$ of the Dutch Copyright Act, indicated by the "Taverne" license above, 
prof dr G.P.J. Keijsers

FPN

\section{The great psychotherapy debate}




\section{The great psychotherapy debate}

prof dr G.P.J. Keijsers

Rede uitgesproken bij de aanvaarding van de leeropdracht: 'Psychologische Behandelingen in het bijzonder ten behoeve van de Specialistische Beroepsopleiding tot Klinisch Psycholoog' bij de Faculty of Psychology and Neuroscience van de Universiteit Maastricht op 25 april 2014.

Referentiewijze: Keijsers, G.P.J. (2014). The great psychotherapy debate: Oratie. Maastricht University. Retrieved from UM Publications.

\section{Mijnheer de rector magnificus,}

geachte toehoorders,

Psychologische behandelingen maken een belangrijk deel uit van onze gezondheidszorg. In 2009 maakten 937.000 mensen gebruik van de ggz (Sectorrapport ggz, 2010). Inmiddels zijn we vermoedelijk de miljoen gepasseerd. Het is belangrijk dat psychologische behandelingen goed zijn en dat het ook helder is waarom ze werken.

Over de werking van psychologische behandelingen is al lange tijd een fundamentele discussie gaande. Bruce Wampold zette deze discussie op scherp met zijn boek 'the great psychotherapy debate' uit 2001. Wampold baseerde zich op empirische gegevens en voerde de discussie met verve. De discussie over de werking van psychotherapie is nu nog net zo actueel als 13 jaar geleden. De titel van de oratie heb ik aan Wampold's boek ontleend.

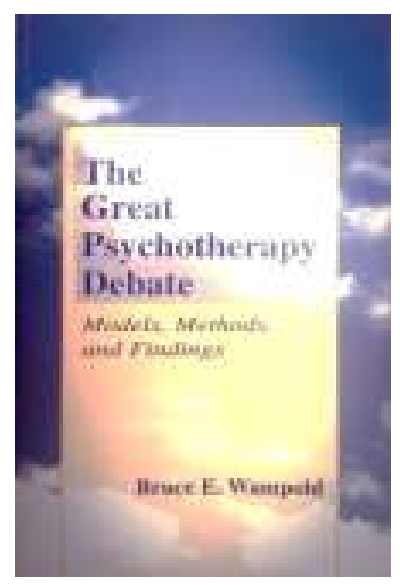

Figuur 1: Wampold's 'The great therapy debate' uit 2001

De grote discussie over de werking van psychotherapie staat dus centraal in deze oratie. De eerste reden daarvoor heeft te maken met het nieuw financieringsbeleid in de ggz. Een flink deel van de psychologische behandelingen die voorheen in de eerste en tweede lijn plaatsvon- 
den, wordt sinds januari 2014 naar de generalistische basis ggz overgeheveld. Binnen de generalistische basis ggz is de omvang van de psychologische hulp echter gelimiteerd. Psychologische behandelingen moeten korter en een deel moet via $e$-health gaan plaatsvinden. Deze ontwikkeling in de ggz in Nederland vergt dat we ons nog beter meer moeten bezinnen op de werking van psychologische behandelingen. Wat moeten we doen in die kortere behandelingen en bij e-health? En letten we op dat we geen belangrijke dingen over het hoofd gaan zien?

Een tweede reden om het grote psychotherapiedebat centraal te stellen in deze oratie betreft de grote verschillen in visie op de werking van psychotherapie. Psychotherapie werkt, dat is zeker, maar we weten onvoldoende waarom. Er zijn bijvoorbeeld grote verschillen in visie hierop tussen de academische wereld en de behandelpraktijk van alle dag. In de vier jaar van hun academische opleiding leren onze studenten allerlei zaken over psychotherapie. Vervolgens doen ze tijdens hun stage en in het postacademisch onderwijs kennis en ervaring op die slecht op die academische kennis aansluiten. Dat is niet goed. Het brengt een verkeerde boodschap over. Dat iedere docent, opleider en begeleider gerust mag uitdragen hoe hij tegen de werking van psychotherapie aankijkt, helpt niet om psychologen stevig neer te zetten in de gezondheidszorg. Garfield en Bergin (1986) noemden dit de 'psychotherapie cafetaria': Iedereen zoekt het zijne wel uit. De 'psychotherapie cafetaria' maakt het gebrek aan een eenduidige visie op de werking van psychotherapie pijnlijk zichtbaar.

In deze oratie stel ik deze visieverschillen aan de orde, ik voer over en weer argumenten aan om vervolgens op compacte wijze weer te geven hoe de werking van psychotherapie in mij ogen het best begrepen kan worden. Dat brengt mij bij de derde reden voor dit onderwerp voor mijn oratie. Ik wil het praktijkveld en de universiteit dichter bij elkaar brengen door hen beiden uit te dagen een stap naar elkaar toe te doen. Psychotherapeuten in de behandelpraktijk wil ik uitdagen een verouderde opvatting over zelfkennis over boord te gooien; experimenteel klinisch psychologen wil ik uitdagen om de zogenaamde 'common factors' van psychotherapie tot serieus onderwerp te gaan maken van experimenteel onderzoek. Onder 'psychotherapie' versta ik in deze oratie overigens alle gangbare vormen van psychologische behandeling.

\section{Psychotherapie werkt vanwege specifieke behandeltechnieken}

In de afgelopen decennia werden voor 40 veelvoorkomende psychische stoornissen psychologische 'Empirically-Supported Treatments' (ESTs) ontwikkeld (Tabel 1). ESTs zijn behandelingen waarvan in meerdere, adequate studies werd aangetoond dat de behandeleffecten beter zijn dan die van andere behandelingen, treatment as usual, placebocondities of wachtlijstconditie (o.a. Carr, 2009, Chambless \& Ollendick, 2001; Fisher \& O'Donohue, 2006; Keijsers et al., 2010; Keijsers, Van Minnen, \& Hoogduin, 2011; Roth \& Fonagy, 2005). ESTs zijn toegespitst op patiënten met specifieke stoornissen, de inhoud van de behandelingen zijn specifiek gemaakt zodat behandelaars de stappen in de behandeling kunnen opvolgen, en de effecten van de behandeling worden met specifieke instrumenten vastgesteld. Het empirische bewijs 
voor de goede effecten van deze ESTs is overweldigend. Het gaat om 4800 studies (Carr, 2009; Keijsers et al., 2011). Mogelijk dat 40 psychische stoornissen niet veel lijkt, maar de meeste van deze stoornissen komen veel voor. Samen vormen ze reden voor aanmelding voor psychologische hulp bij naar schatting 70 procent van alle patiënten in de gezondheidszorg (Sectorrapport ggz, 2010; Veerbeek, Knispel, \& Nuijen, 2012).

\begin{tabular}{|l|l|l|}
\hline Angststoornissen & Depressie & Middelenmisbruik \\
- Gegeneraliseerde angststoornis & - Bipolaire stoornis & - Alcoholmisbruik/-verslaving \\
- Obsessieve-compulsieve stoornis & - Unipolaire stoornis & - Cocaïnemisbruik/-verslaving \\
- Paniekstoornis & - Unipolaire stoornis bij ouderen & - Opiatenmisbruik/-verslaving \\
- Posttraumatische stressstoornis & & - Nicotineverslaving \\
- Sociale fobie & & \\
- Specifieke fobie & & \\
\hline Eetstoornissen & Somatoforme stoornissen en pijn & Relatieproblemen en seksuele \\
- Anorexia nervosa & - Conversiestoornis & problemen \\
- Boulimia nervosa & - Stoornis in de lichaamsbeleving & - Relatieproblemen \\
- Eetbuistoornis & - Hypochondrie & - Erectiestoornis \\
- Obesitas & - Chronische vermoeidheid & - Vrouwelijk orgasmestoornis \\
& - Somatoforme pijnstoornis & - Vaginisme en dyspareunie \\
& - Chronische lage rugpijn & - Stoornis in seksuele verlangen \\
& - Spanningshoofdpijn & - Parafilia \\
\hline Impulscontrolestoornissen & - Migraine & \\
- Periodieke explosieve stoornis & Persoonlijkheidsstoornissen & Overige condities \\
en agressie & Vermijdende persoonlijkheidsstoor- & - Schizofrenie \\
- Ongewenste gewoonten & nis en cluster C & - Insomnia en overige slaap- \\
- Pathologisch gokken & - Borderline persoonlijkheidsstoornis & stoornissen \\
- Automutilatie & & - Dementie \\
\hline
\end{tabular}

Tabel 1: Overzicht van DSM-IV stoornissen waarvoor ESTs ontwikkeld werden. Uit Keijsers et al. (2011), pp. 30-34.

Bij deze voorstelling van zaken doet zich wel een probleem voor. Het probleem is dat bij ESTs niet goed kan worden vastgesteld wat nu precies het essentiële ingrediënt van de behandeling is. ESTs bestaan vaak uit pakketten van interventies. Via zogenaamde ontmantelingsstudies zou vast te stellen moeten zijn welke van deze interventies essentieel zijn voor het therapeutische effect. De behandelingen pretenderen immers specifiek te zijn, dus wat precies bepaalt het effect? In de 'great psychotherapy debate' wijst Wampold erop dat deze ontmantelingsstudies weinig hebben opgeleverd. We beschikken over ESTs maar toch is het niet goed mogelijk om de specifiek werkzame onderdelen van een psychologische behandeling te vinden. Hoe kan dat? Zijn alle onderdelen van zo'n pakket dan even belangrijk? Daar komt nog een probleem bij. Voor de 40 psychische stoornissen werden 110 ESTs ontwikkeld; voor de meeste stoornissen meerdere behandelingen. Voor patiënten met unipolaire depressie, bijvoorbeeld, werden maar liefst acht psychologische ESTs vastgesteld (Tabel 2). Daartoe behoren cognitieve therapie, gedragsactivatie, interpersoonlijke psychotherapie en kortdurende psychodynamische psychotherapie (Keijsers et al., 2011). Hoe kunnen meerdere, behoorlijk 
verschillende behandelingen, allemaal een goed effect hebben? Opnieuw is dan de vraag wat specifiek is voor de bereikte behandelresultaten.

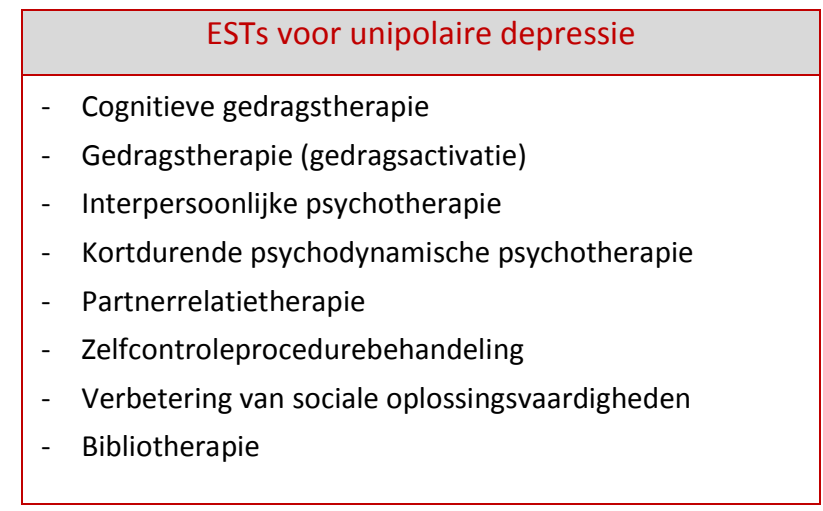

Tabel 2: Overzicht van ESTs voor unipolaire depressie. Uit Keijsers et al. (2011), p. 31.

Het antwoord van Wampold luidt dat de specifieke technieken uit de behandelpakketten alleen maar een marginale bijdrage leveren aan het effect van psychologische behandelingen. Wat alle behandelingen namelijk gemeen hebben is dat de technieken worden toegepast in een speciale therapeutische context, ook wel aangeduid met 'common factors', waarbij vooral de kwaliteit van de werkrelatie verantwoordelijk gehouden wordt voor het effect van psychotherapie.

Binnen het praktijkonderwijs en het praktijkveld bestaat veel sympathie voor deze opvatting: 'Uiteindelijk is het toch het goede therapeutische contact waardoor patiënten opknappen'. Ter ondersteuning van deze opvatting verwijst men binnen het praktijkonderwijs, ook in recente handboeken (bijv. Colijn, Snijders, \& Trijsburg, 2009), graag naar de zogenaamde 'cirkel van Lambert' (Figuur1). De 'cirkel' is immers ontwikkeld door een gerenommeerd kenner van de onderzoeksliteratuur.
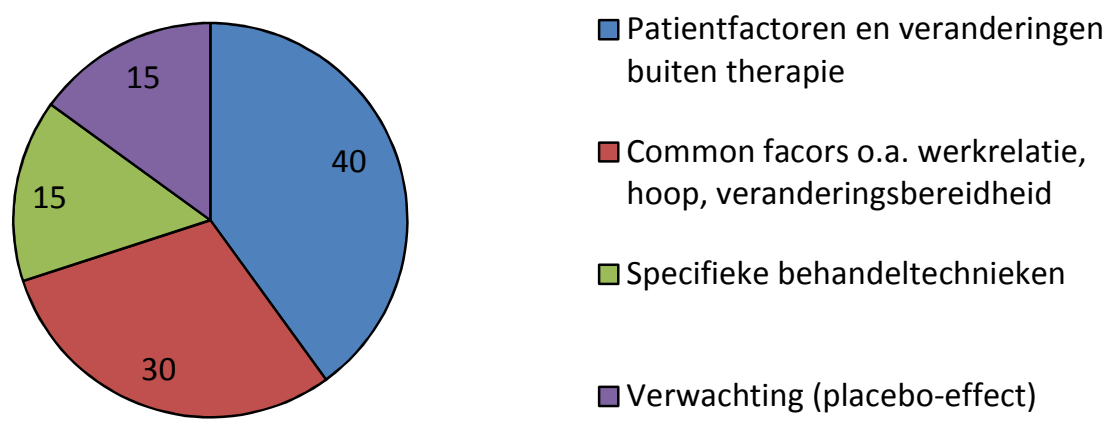

Figuur 1. Cirkel van Lambert: Bijdragen (percentages) aan het effect van psychotherapie. Uit Lambert (1992), p. 97.

De 'cirkel' bestaat uit een taartdiagram die het totale effect van therapie op 100 procent stelt en de taart vervolgens in stukken verdeelt die alle aan het totale effect bijdragen. Dertig pro- 
cent van het psychotherapieresultaat wordt verkregen via 'common factors' zoals de werkrelatie, en 15 procent, slechts de helft hiervan dus, via specifieke behandeltechnieken. Omdat deze 'cirkel' in het psychotherapieonderwijs zo vaak aangehaald wordt, is het interessant om enige achtergrondinformatie over de 'cirkel' te bieden.

De 'cirkel van Lambert' verscheen voor het eerst in een handboekhoofdstuk van Lambert uit 1992. Ze is gebaseerd op een literatuuroverzicht uit 1986 (Lambert, Shapiro, \& Bergin, 1986) en betreft psychotherapiestudies tot aan 1984. De brongegevens zijn tussen de 30 tot 54 jaar oud. De getallen uit de cirkel komen niet uit statistische analyses, maar zijn schattingen (Lambert, 1992; Wampold, 2001; van Yperen et al., 2010). Het is allerminst zeker of behandelingen van 50 jaar geleden wel vergelijkbaar zijn met huidige behandelingen. Evenmin is het zeker of behandelstudies uit die periode wel zouden voldoen aan de methodologische eisen van nu. Verder bevat het model twee denkfouten. We kunnen het effect van psychotherapie allerminst 100 procent verklaren en evenmin kunnen we die unieke onderdelen onderscheiden omdat ze veel te sterk verweven zijn (DeRubeis, Brotman, \& Gibbons, 2005). De cirkel vertroebelt visies op psychotherapie meer dan ze behulpzaam is. Hoewel aantrekkelijk in haar eenvoud, is het jammer dat de cirkel zo vaak herhaald wordt.

Ik keer weer terug naar het antwoord van Wampold: Heeft Wampold gelijk en zijn common factors zoals de kwaliteit van de werkrelatie beduidend belangrijker voor het effect van psychotherapie dan de specifieke behandeltechnieken? Zou dat kunnen? Ook bij dit antwoord zijn er problemen. Vijf grote metastudies naar de therapeutische alliantie en de kwaliteit van therapeutische relatie tussen 1991 en 2011, met elk meer dan honderd bronstudies (Elliott et al., 2011; Horvath \& Bedi, 2002; Horvath \& Symonds, 1991; Horvath, Flückiger, \& Symonds, 2011; Martin, Garske, \& Davis, 2000), maken duidelijk dat de kwaliteit van de werkrelatie inderdaad een consistente correlatie van .22 tot .27 vertoont met het behandelresultaat. Omgerekend naar Cohen's $d$, de belangrijkste effectmaat binnen psychotherapie-onderzoek, is dat een effect van 0.45 tot 0.55 . Dat is een matig sterk effect, niet groot, maar ook niet klein. ${ }^{1}$

Het is niet uitgesloten dat deze correlaties bepaald worden door goed verbeterde patiënten die om die reden tevreden terugblikken op het contact met de therapeut: Metingen in de laatste drie behandelsessies vertonen inderdaad een relatief sterke samenhang met het behandelresultaat. Maar toch is dat waarschijnlijk niet de enige verklaring. Ook vroege metingen van de werkrelatie, metingen in de eerste vijf behandelsessies, vertonen deze samenhang met het behandelresultaat (Horvath \& Bedi, 2002, Horvath et al., 2011, Wampold, 2001). Van de andere kant is het toch lastig om het belang van de werkrelatie goed te begrijpen. Lastig bij-

\footnotetext{
${ }^{1}$ Een Cohen's $d$ van 0.5 wordt als een matig sterk effect beschouwd, een redelijk groot effect dus, vindt Wampold. Toch is het niet zeker of de gevonden correlaties als matig sterk gezien mogen worden. Om de correlaties om te zetten naar Cohen's $d$ gebruikte Wampold een correspondentieberekening. Die berekening is gebaseerd op punt-biseriële correlaties (Rosenthal, Rosnow, \& Rubin, 2000). De correlaties tussen werkrelatie en therapieresultaat zijn echter product-momentcorrelaties. Gebruikelijk bij product-momentcorrelaties is de proportie verklaarde variantie te hanteren om de grootte van een effect te verduidelijken. Die proportie verklaarde variantie bedraagt $4.8 \%$ tot $7.2 \%$.
} 
voorbeeld is dat de patiënt- en therapeutbeoordeling van de werkrelatie niet erg overeenkomen. Als de therapeut tevreden is over de samenwerking, hoeft het niet zo te zijn dat ook de patiënt tevreden is. Correlaties tussen .09 en .43 worden gerapporteerd. Je zou een sterkere samenhang verwachten omdat bij de gangbare instrumenten om de kwaliteit van de werkrelatie en van de therapeutische relatie te meten, de therapeutversie analoog is aan de patiëntversie en beide versies bij dezelfde sessies worden afgenomen (o.a. Bøgwald, 2001; Meier \& Donmall, 2005, Keijsers, Schaap, \& Hoogduin, 2000). Verder is het zo dat de samenhang van beide beoordelingen met het behandelresultaat ook niet het zelfde is. De samenhang met behandelresultaat is sterker als de patiënt de kwaliteit van de werkrelatie beoordeelt en beduidend zwakker als de therapeut dat doet (Tabel 3). Cruciaal is dus de patiëntbeoordeling van die relatie (Horvath et al., 2011; Wampold, 2001).

\begin{tabular}{|l|c|c|}
\cline { 2 - 3 } \multicolumn{1}{c|}{} & \multicolumn{1}{c|}{$\begin{array}{c}\text { Therapieresultaat } \\
\text { volgens de patiënt }\end{array}$} & $\begin{array}{c}\text { Therapieresultaat } \\
\text { volgens onafhankelijke } \\
\text { beoordelaars }\end{array}$ \\
\hline $\begin{array}{l}\text { Kwaliteit van de werkrelatie } \\
\text { volgens de patiënt }\end{array}$ & $.30(98)$ & $.21(40)$ \\
\hline $\begin{array}{l}\text { Kwaliteit van de werkrelatie } \\
\text { volgens de therapeut }\end{array}$ & $.18(31)$ & $.13(20)$ \\
\hline
\end{tabular}

Tabel 3. Correlaties (en aantal studiebevindingen). Uit Horvath et al. (2011), p. 53.

Tot slot zou het begrijpelijk zijn geweest als de samenhang met het behandelresultaat het sterkst was bij persoonsgerichte psychotherapie en psychoanalyse. Binnen deze therapievormen wordt de werkrelatie immers als het belangrijkste instrument gezien om patiënten te helpen te veranderen. Dat is echter niet het geval. De samenhang met het behandelresultaat is zeker niet geringer (zie ook Bohart et al., 2002) bij andere therapievormen zoals cognitieve gedragstherapie (Tabellen 4 en 5).

\begin{tabular}{|l|l|}
\hline Psychoanalyse (psychodynamisch) & $.17(7)$ \\
\hline Eclectisch/gemengde therapie & $.28(10)$ \\
\hline Cognitieve gedragstherapie & $.26(4)$ \\
\hline
\end{tabular}

Tabel 4. Correlaties tussen werkrelatie en behandelresultaat (en aantal). Uit Horvath en Symonds (1991), p. 145.

\begin{tabular}{|l|l|}
\hline Psychoanalyse (psychodynamisch) & $.19(4)$ \\
\hline Persoonsgerichte psychotherapie & $.26(8)$ \\
\hline Cognitieve gedragstherapie & $.31(10)$ \\
\hline
\end{tabular}

Tabel 5. Correlaties tussen empathie en behandelresultaat (en aantal). Uit Elliott et al. (2011), p. 141.

Er zijn dus nogal wat onduidelijkheden bij Wampold's visie en de belangrijkste is misschien nog wel dat het onduidelijk is op welke wijze de werkrelatie bijdraagt aan het behandelresultaat. De werkrelatie helpt de patiënt bij het veranderingsproces, maar de visies over 
hoe dat gebeurt verschillen nogal per therapiestroming. Dus als iemand beweert dat het 'uiteindelijk toch het goede therapeutische contact is waardoor patiënten opknappen' dan blijft de vraag bestaan waarom en volgens welke psychologische processen dit behandelresultaat dan bereikt wordt. We kunnen daarom vaststellen dat Wampold's bewering in 'the great psychotherapy debate' zeer waarschijnlijk wel terecht is dat de kwaliteit van werkrelatie, ten minste zoals beoordeeld door de patiënt, een consistente bijdrage levert aan het behandelresultaat van psychotherapie. We moeten tegelijkertijd vaststellen dat we weinig weten over hoe dat werkt.

Hoe zit het met de andere bewering van Wampold? Wampold stelt namelijk dat empirische data duidelijk maken dat behandeltechnieken er nauwelijks toe doen. In de psychotherapieliteratuur staat deze opvatting bekend als het 'dodo-bird verdict'. Deze opvatting houdt in dat alle vormen van psychotherapie bij benadering vergelijkbaar effectief zijn. De benaming komt uit het kinderboek 'Alice in wonderland' waarin de dodo na een hardloopwedstrijd geen verliezers durfde aan te wijzen en dus besliste dat iedereen gewonnen had. In de discussie over het dodo-bird verdict neemt Wampold een unieke positie in vanwege zijn studie uit 1997. Tot dan toe werd het empirische bewijs voor het dodo-bird verdict afgeleid uit grote metastudies waarin allerlei patiëntpopulaties en allerlei behandeltechnieken op elkaar gegooid werden. Zo'n opeenstapeling van 'appels en peren' maakt conclusies over de bijdrage van behandeltechnieken aan het resultaat van psychotherapie onmogelijk. Wampold pakte het echter beter aan. Via een meta-analyse onderzochten Wampold et al. (1997) effectgrootteverschillen bij honderden vergelijkingen tussen bonafide behandelingen in studies tussen 1970 en 1995. Daarbij werden alleen directe effecten in de berekeningen meegenomen, dat wil zeggen, alleen de effecten van vergelijkingen binnen elke studie. Het effect van een bepaalde behandeltechniek in vergelijking met een andere behandeltechniek bleek gemiddeld 0.19 te bedragen. Een Cohen's $d$ van 0.19 wordt als een klein effect beschouwd. Wampold et al. concludeerden dan ook dat behandeltechnieken weinig bepalend zijn voor het behandelresultaat. ${ }^{2}$

De bevindingen uit Wampold's meta-analyse dat behandelmethoden weinig bepalend zijn voor het behandelresultaat, deden veel stof opwaaien. De bevindingen lijken slecht verenigbaar met het uitgebreide en overtuigende onderzoek naar ESTs. Toch zijn ze dat niet. Wampold et al. lieten vergelijkingen met wachtlijstcondities achterwege. Alleen directe vergelijkingen tussen bonafide behandelcondities werden in de analyses meegenomen. Inspectie van de bronstudies van deze meta-analyse laten bovendien zien dat driekwart van de vergelijkingen vergelijkingen zijn tussen varianten van cognitieve gedragstherapie (CritsChristoph,1997; Hunsley \& Di Guilio, 2002). Een effect size van 0.19 is het verschil tussen twee bonafide psychologische behandelingen. Dat is niet anders dan men binnen de ESTtraditie ook aanneemt. Er zijn grote groepen patiënten nodig om verschillen tussen bonafide

\footnotetext{
${ }^{2}$ Feitelijk concludeerden Wampold et al. (1997) dat Cohen's $d$ voor specifieke behandeltechnieken op zijn hoogst 0.1 zou bedragen, maar Howard et al. (1997) maken duidelijk dat de uiteindelijke rekenmethode van de auteurs onjuist was en dat hun eerdere rekenmethode met een $d$ van 0.19 aangehouden dient te worden.
} 
behandelingen aan te tonen (o.a. Kazdin \& Bass, 1989). Daaruit valt echter niet af te leiden, zoals Wampold dat doet, dat behandeltechnieken er niet toe doen. Een metafoor om dat te verduidelijken is wellicht behulpzaam: Laten we eens aannemen dat je ongeveer even snel in het hartje Parijs bent met een snelle auto of met de highspeed trein. De verschillen in aankomsttijd zijn klein, stellen we vast. De vraag is dan of we daaruit kunnen concluderen dat vervoersmiddelen maar een kleine bijdrage leveren aan reizen.

Zoals gezegd bestaan ESTs meestal uit pakketten van behandeltechnieken die specifiek zijn gemaakt voor bepaalde groepen patiënten. Steeds duidelijker tekent zich bij ESTs een matrixmodel af (Tabel 6): Interventies zijn enerzijds specifiek gemaakt voor de behandeling van afzonderlijke stoornissen, zoals paniekstoornis, posttraumatische stressstoornis of unipolaire depressie. Anderzijds zijn ESTs ontworpen om op cognitieve processen ${ }^{3}$ in te grijpen die aan deze stoornissen ten grondslag liggen.

\begin{tabular}{|c|c|c|c|c|}
\hline \multirow[b]{2}{*}{$\begin{array}{l}\text { Psychische stoor- } \\
\text { nissen }\end{array}$} & \multicolumn{4}{|c|}{ Verstoorde cognitieve processen } \\
\hline & $\begin{array}{l}\text { Catastrofale ver- } \\
\text { wachtingen on- } \\
\text { dermijnen }\end{array}$ & $\begin{array}{c}\text { Redenatie- en } \\
\text { interpretatiefouten } \\
\text { zichtbaar maken en } \\
\text { bijsturen }\end{array}$ & $\begin{array}{l}\text { Reallocatie van aan- } \\
\text { dacht trainen, belasting } \\
\text { van werkgeheugen } \\
\text { beinnvloeden }\end{array}$ & $\begin{array}{c}\text { Gedragsalternatieven of } \\
\text { alternatieve herinnerin- } \\
\text { gen trainen }\end{array}$ \\
\hline $\begin{array}{l}\text { Fobieën, GAS, } \\
\text { paniekstoornis, }\end{array}$ & exposure & $\begin{array}{l}\text { cognitieve therapie, } \\
\text { cognitieve bias } \\
\text { modificatie }\end{array}$ & taakconcentratie & applied relaxation \\
\hline $\begin{array}{l}\text { - Posttraumatische } \\
\text { stressstoornis }\end{array}$ & Exposure, EMDR & & EMDR & imagery rescripting \\
\hline $\begin{array}{l}\text { Obsessieve-com- } \\
\text { pulsieve stoornis }\end{array}$ & exposure & cognitieve therapie & & responspreventie \\
\hline $\begin{array}{l}\text { - Unipolaire depres- } \\
\text { sie }\end{array}$ & & $\begin{array}{l}\text { cognitieve therapie, } \\
\text { cognitieve bias } \\
\text { modificatie }\end{array}$ & geheugentraining & gedragsactivering \\
\hline - Eetstoornissen & & & spiegeltraining & $\begin{array}{l}\text { zelfcontrole- } \\
\text { procedures }\end{array}$ \\
\hline $\begin{array}{l}\text { - Stoornis in de } \\
\text { lichaamsbeleving }\end{array}$ & & cognitieve therapie & spiegeltraining & \\
\hline $\begin{array}{l}\text { - Impulscontrole- } \\
\text { stoornissen, tics }\end{array}$ & & & & $\begin{array}{l}\text { habit reversal, zelf- } \\
\text { controleprocedures }\end{array}$ \\
\hline - Hypochondrie & exposure & cognitieve therapie & & responspreventie \\
\hline - Verslaving & & $\begin{array}{l}\text { cognitieve bias } \\
\text { modificatie }\end{array}$ & $\begin{array}{l}\text { executieve controle } \\
\text { training }\end{array}$ & $\begin{array}{l}\text { sociale vaardigheids- } \\
\text { training, zelfcontrole- } \\
\text { procedures }\end{array}$ \\
\hline
\end{tabular}

Tabel 6: Matrixmodel: voorbeelden.

\footnotetext{
${ }^{3}$ De term 'cognitieve processen' wordt hier in heel algemene zin gebruikt. Het had ook 'mentale processen' kunnen zijn, maar wat is 'mentaal'? Het woord 'cognitief' verraadt wel een voorkeur om begrippen als 'associatie' of 'contingentie' uit de leerpsychologie of 'neuraal netwerk' of 'synaptogenese' uit de neurowetenschappen vanuit een cognitief-psychologisch perspectief te bestuderen.
} 
ESTs zijn gericht op veranderingen van aanhoudende of telkens terugkerende ongewenste gedachten, emoties of gedrag en ze zijn werkzaam omdat ze interveniëren op veronderstelde onderliggende cognitieve processen. Er wordt gepraat, maar er wordt ook veel geoefend, binnen en buiten de sessies (Keijsers \& Becker, 2009; Keijsers, Woud, \& Becker, 2009). Systematische trainingsprogramma's over de weken heen komen vaak voor. Tabel 6 biedt een illustratie van verstoorde cognitieve processen, trainingsprogramma's en psychische stoornissen. Om catastrofale verwachtingen te ondermijnen worden exposureprogramma's ingezet bij bijvoorbeeld patiënten met angststoornissen (o.a. Craske et al., 2008; Hofman, 2008), posttraumatische stressstoornis (o.a. Van Minnen \& Arntz, 2011) en obsessief-compulsieve stoornis (o.a. Verbraak, Hoogduin, \& Keijsers, 2011). Verandering van redenatiefouten en negatieve interpretaties wordt aangepakt met behulp van cognitieve therapie bij bijvoorbeeld patiënten met paniekstoornis (o.a. Kampman, Keijsers, \& Hendriks, 2011; Schmidt \& Keough, 2010), hypochondrie (o.a. Bouman, Visser, \& Vervaeke, 2011) en unipolaire depressie (o.a. Craighead et al., 2007). Voor reallocatie van aandacht worden programma's als taakconcentratie en spiegeltraining ingezet bij bijvoorbeeld patiënten met sociale fobie (o.a. Bögels \& Mansell, 2004), eetstoornissen (Smeets, Jansen, \& Roefs, 2011) en stoornis in de lichaamsbeleving (o.a. Neziroglu \& Santos, 2013). Gedragsalternatieven worden ingeoefend met behulp van zelfcontroleprocedureprogramma's en habit reversal bij bijvoorbeeld patiënten met ongewenst gewoontegedrag (o.a. Keijsers, Van Minnen, \& Hoogduin, 2006; Van Minnen et al., 2003) en tics (Verdellen et al., 2004). Op dit moment worden ook behandeleffecten onderzocht van trainingen via computerprogramma's om impliciete aandacht-, -evaluatie-, interpretatie- en geheugenprocessen te beïnvloeden bij diverse psychische stoornissen (o.a. Eberl et al., 2013; Hallion \& Ruscio, 2011; MacLeod \& Mathews, 2012).

Er is overweldigend bewijs dat ESTs met een specifieke focus op klachten en onderliggende cognitieve processen bijzonder effectief zijn. De gebruikelijke effecten van ESTs (Cohen's $d$ ) liggen tussen 1 en 3 (Keijsers et al., 2011). Het matrixmodel maakt ook begrijpelijk waarom voor veel stoornissen meerdere ESTs ontwikkeld konden worden. ESTs kunnen op diverse cognitieve processen van een stoornis aangrijpen. Wanneer Erica een specifieke fobie heeft voor muizen is het begrijpelijk dat ze een verhoogde aandacht heeft voor geritsel of bewegingen in de hoek van een kamer. Ook is het niet verwonderlijk dat Erica denkt het niet te kunnen verdragen als er plots een muis door de kamer rent. Deze angst maakt dat ze zolders en schuren gaat vermijden. Deze vermijding bevestigt weer haar catastrofale verwachtingen. Zelfs bij stoornissen zoals deze relatief eenvoudige muizenfobie zijn dus diverse, op elkaar ingrijpende cognitieve processen ontregeld. Dat maakt begrijpelijk dat meerdere van elkaar verschillende behandeltechnieken, zoals exposure of cognitieve therapie effectief kunnen ingrijpen op deze samenhangende processen. De technieken zijn specifiek, maar grijpen niet op dezelfde wijze op dezelfde onderliggende cognitieve processen aan. Meerdere ESTs zijn mogelijk. De toenemende kennis dat bij psychische stoornissen meerdere cognitieve processen ontregeld zijn, verklaart ook de interesse in transdiagnostische processen binnen de experi- 
mentele klinische psychologie van de laatste jaren (Emmelkamp et al., 2014; Harvey et al., 2006).

Natuurlijk heeft Wampold wel gelijk dat de bijdrage van common factors zoals de werkrelatie ook in de behandeleffecten van ESTs besloten liggen. Ook bij ESTs worden behandelingen in de regel uitgevoerd in een nauwe samenwerking tussen patiënt en therapeut. Bovendien legt Wampold terecht bloot dat psychotherapie-onderzoekers mogelijk niet zorgvuldig genoeg zijn in de bespreking van grote en kleine therapie-effecten: Het vinden van grote of kleine behandeleffecten in gecontroleerde behandelstudies hangt sterk af van de kwaliteit van de controleconditie. Grote behandeleffecten zijn gemakkelijker te vinden als verschillen worden berekend met een wachtlijstconditie, een placeboconditie of een TAU-conditie waarbij de onderzoekers niet investeren in die controleconditie in termen van extra training of extra controle. Dat is veel gebeurd in het onderzoek naar ESTs. Een zelfde effect aantonen tussen twee stoornisspecifieke, bonafide behandelingen is moeilijk en vereist grote groepen patiënten. ${ }^{4}$ Dat is lang niet altijd gebeurd. Onderzoekers kunnen daarin duidelijker zijn.

Ik keer weer terug naar de 'great psychotherapy debate'. Wampold beweert dat er weinig redenen zijn om aan te nemen dat specifieke behandeltechnieken er toe doen. De grote hoeveelheid onderzoeksgegevens bij ESTs stellen hem in het ongelijk. Het dodo-bird verdict is een mythe. Bij de eerder genoemde 40 veelvoorkomende stoornissen zijn bepaalde behandelingen beslist beter dan andere (o.a. Hunsley, \& Di Guilio, 2002; Keijsers et al., 2011).

\section{Psychotherapie werkt vanwege common factors}

Therapeutische technieken zijn dus van groot belang. Maar ook is het een empirisch gegeven dat common factors zoals de kwaliteit van de werkrelatie van invloed zijn op het behandelresultaat van psychologische behandelingen. De vraag is echter hoe dat komt. Waarom zijn common factors belangrijk? Als we vasthouden aan de dominante, existentieel-humanistische visie uit de behandelpraktijk, dan belanden deze common factors niet op de onderzoeksagenda van universiteiten. Maar ze horen daar wel thuis. Ik heb Wampold in deze oratie in meerdere opzichten in het ongelijk gesteld. Ik heb gewezen op de zwakke uitgangspunten van de 'cirkel van Lambert' en ik heb me uitgesproken tegen het dodo-bird verdict en tegen het idee dat het 'toch het goede therapeutische contact is dat iemand beter maakt'. Nu wil ik uitdrukkelijk ook een lans breken vóór het werk van Wampold.

\footnotetext{
${ }^{4} \mathrm{Bij}$ deze discussie is ook de volgende observatie van Ollendick en King (2006) relevant: Bij vergelijkbare effecten van twee bonafide behandelingen speelt beslist ook mee dat onderzoekers het moeilijk voor elkaar krijgen om een 'slecht passende' bonafide behandeling (bijvoorbeeld responspreventie voor patiënten met unipolaire depressie) met een goed passende, bonafide behandeling te vergelijken. Een wachtlijstconditie in een patiëntstudie vraagt al grote zorgvuldigheid. Patiënten met een bepaalde stoornis een behandeling laten ondergaan waarvoor geen theoretische of empirische grond bestaat om een effect te verwachten, is om ethische redenen ontoelaatbaar.
} 
Vanuit de ontstaansgeschiedenis van de psychotherapie valt goed te typeren wat psychoanalytici en psychotherapeuten in de negentiende en twintigste eeuw met psychotherapie wilden bewerkstelligen. Mede door de opkomst van het empirisme en de wetenschap in de negentiende eeuw, maakten klassieke thema's zoals de verhouding tussen lichaam en ziel, het zoeken naar moraal en absolute waarheden, plaats voor een nieuwe visie op de mens, de mens als een autonoom en verantwoordelijk individu. Het streven naar zelfkennis, al populair in de verlichting, kwam op een nog hoger plan en beïnvloedde het ontstaan en de ontwikkeling van de psychotherapie (Bakker, van Melsen, \& van Peursen, 1985; Mahoney, 1991). Zowel de psychoanalyse als de humanistische psychotherapie hadden tot doel zelfinzicht te bewerkstelligen en daarmee de mens te bevrijden van symptomen. De methode daartoe was zelfinzicht en de ontwikkeling van het zelf (Figuur 2), op vergelijkbare wijze als Socrates dat deed in het Athene van de vierde eeuw voor Christus. Het helende gesprek stond centraal. In dat gesprek kon de patiënt zichzelf onder ogen komen.

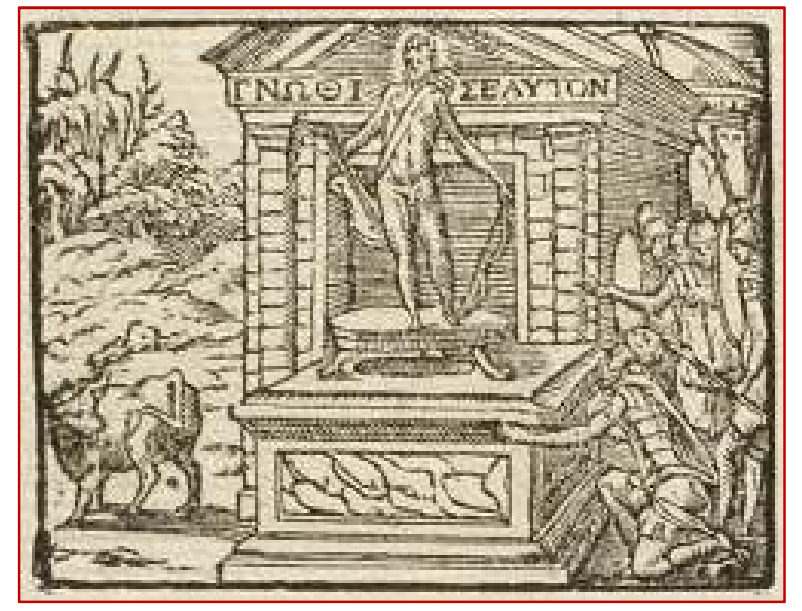

Figuur 2: 'Gnothi Seauton', 'ken uzelf', oud-Grieks aforisme. Gravure komt uit Picta poesis (1552) van Barthélemy Aneau, een Frans dichter en humanist. Bron: www.emblems.arts.gla.ac.uk.

Nog steeds is het 'ken uzelf'- ideaal dominant aanwezig in onze cultuur. Ze is ook aanwezig in de psychologische behandelpraktijk, maar ze past slecht in de huidige empirische en wetenschappelijke visie op psychologische veranderingsprocessen. ${ }^{5}$ De traditionele psychotherapie met het 'ken uzelf'-ideaal is gericht op persoonlijke ontwikkeling. ESTs zijn dat niet. ESTs zijn veranderingsgericht. Ze zijn ontwikkeld om aanhoudend ongewenst gedrag, gevoelens of gedachten op effectieve en efficiënte wijze te verminderen via empirisch gevalideerde metho-

\footnotetext{
${ }^{5}$ Feitelijk is het idee dat men via zelfreflectie betere zelfkennis kan bereiken theoretisch weinig gefundeerd. Er is weinig bewijs voor het bestaan van onbewuste conflicten, noch voor het succesvol weghouden van informatie uit de bewuste aandacht gedurende een lange periode. Er zijn tal van onbewuste cognitieve processen, maar daar toe kunnen we, ook met training, nauwelijks bewuste toegang verkrijgen. De metafoor dat we 'als archeologen in onszelf moeten graven' is weinig adequaat. Adequater en ook zinvol voor nadere bestudering is dat mensen een zelfconcept construeren en via geconstrueerde narratieven vertellen wie ze zijn. Zie Wilson en Dunn (2004) voor een voortreffelijk overzicht van de wetenschappelijke literatuur hieromtrent.
} 
dieken (Barlow, 1997). Het wordt tijd om ook binnen deze veranderingsgerichte visie op psychotherapie de common-factors serieus te gaan nemen. Dat kan. Het is een kwestie van klaarliggende puzzelstukken in elkaar passen. Daartoe doe ik het volgende voorstel. Graag leg ik een visie voor op common factors en werkrelatie die:

1. recht doet aan ervaringen van behandelaars en psychotherapeuten in de praktijk en verklaart waarom studenten in de praktijk heel ander zaken leren over psychotherapie dan in het academische onderwijs aan de universiteit;

2. aansluit bij de uitgebreide, maar nogal anekdotische vakliteratuur over moeilijk te behandelen patiënten;

3. verklaart waarom common factors belangrijk zijn voor het behandelresultaat van psychotherapie en met name als de patiënt de werkrelatie beoordeelt en beslist ook in de eerste sessies;

4. gebaseerd is op goed onderzochte psychologische theorieën met circa 1200 Engelstalige empirische studies in peer-reviewed tijdschriften tussen 1938 en $2014 .^{6}$

Voordat ik een indruk geef van dit onderzoeksveld, bied ik eerst enkele impressies uit de praktijk. In 1987 publiceerde Allan Carr het zelfhulpboek 'The easy way to stop smoking'. Zijn methode om te stoppen staat beschreven in een van laatste hoofdstukken van het boek en bestaat uit niet veel meer dan het volgende: 'Doof de laatste sigaret en steek er nooit meer een op'. De hoofdstukken die aan deze nogal kernachtige behandelmethode voorafgaan, bestaan uit uitgebreide beschrijvingen van de wijze waarop de auteur, zelf een kettingroker, zijn eigen rookgedrag vergoelijkte: 'mijn sigaret is mijn vriend', 'roken geeft me zelfvertrouwen', en zo voort. Die tekst is zo herkenbaar en zo ontluisterend dat miljoenen rokers over de hele wereld met behulp van dit boek gestopt zijn met roken. ${ }^{7}$

Carr bouwde zijn boek op rond het verminderen van weerstand en vergroten van bereidheid om te veranderen (Schippers \& Kampman, 1999). Het is geen toeval dat binnen de verslavingsliteratuur belangrijke modellen ontwikkeld werden over het begrijpen van weerstand, het nog niet klaar zijn voor behandeling, het niet geloven dat de behandeling gaat werken, en zo voort (o.a. Prochaska, DiClemente, \& Norcross, 1992). Ook is het geen toeval dat binnen de verslavingsliteratuur belangrijke behandelmethoden ontwikkeld werden om die weerstand te overwinnen. Motivational interviewing is een kortdurende behandeling gericht op het creeren en bestendigen van de motivatie om met het verslavende middel te stoppen. Motivational interviewing geldt als een EST bij alcoholverslaving en is even effectief als langdurende effectieve behandelingen (Miller, Wilbourne, \& Hettema, 2003; de Wildt et al., 2011).

\footnotetext{
${ }^{6}$ De trefwoordencombinatie 'social influence OR persuasion' met daaraan toegevoegd de restricties 'peer reviewed journal AND empirical study' leverde 1201 treffers op bij een zoekopdracht met het elektronische zoeksysteem PsycINFO op 20 februari 2014.

${ }^{7}$ Het idee over het succes van het boek van Carr komt van Schippers en Kampman (1999).
} 
Weerstand tegen verandering en beïnvloeding is niet voorbehouden aan patiënten met verslavingen. Ze wordt gerapporteerd bij patiënten met allerlei soorten klachten: angstklachten, trauma's, eetstoornissen, somatoforme stoornissen, chronische vermoeidheid, impulscontroleproblemen, bipolaire stoornis en persoonlijkheidsstoornissen. Ze wordt gerapporteerd bij chronische patiënten, somatiserende patiënten, adolescenten en delinquenten.

Vier jaar academisch onderwijs krijgen onze studenten. Dan gaan ze stage lopen. Dat een exposurepogramma opgezet moet worden is duidelijk, of dat een patiënt een training in cognitieve therapie moet ontvangen. Maar de eerste dag al gaat het mis. De patiënt ziet zo'n stagiaire niet zitten, de patiënt verklaart al weer beter te zijn of de patiënt meldt met heel andere zaken bezig te zijn dan met zijn angst voor enge ziektes. Een belangrijk deel van psychotherapie bestaat eruit bij de patiënt de bereidheid te creëren en te onderhouden om te veranderen. Het is onaangenaam en vaak ook verrassend moeilijk om je gedrag te veranderen ook al heb je er last van (Keijsers, Vossen, \& Keijsers, 2012, 2013). Weerstand tegen verandering van eigen gedrag is universeel en vormt een groot onderzoeksterrein binnen de sociale psychologie en communicatiewetenschap.

De gedachtegang binnen dat onderzoeksterrein is niet zo ingewikkeld. De wijze waarop mensen zich in hun gedrag en opvattingen door anderen laten beïnvloeden kent wetmatigheden. Weerstand is een reactie tegen verandering en kan gericht zijn tegen zowel de inhoud van het veranderingsvoorstel, bijvoorbeeld als iemand gevraagd wordt om een tijdrovende huiswerkopdracht uit te voeren, of tegen de wijze waarop het veranderingsvoorstel gebracht wordt, bijvoorbeeld als iemand iets tracht af te dwingen. Ik geef enkele voorbeelden van uitgebreid bestudeerde modellen over weerstand tegen beïnvloeding.

De sociaalpsycholoog, Brehm ontwikkelde het begrip 'reactance'. Reactance is een vorm van verzet die optreedt als mensen menen dat hun vrijheid en hun controle over hun eigen leven in het gedrang komt. Reactance is gemakkelijk op te wekken en de effecten zijn robuust. Men houdt vast aan de eigen mening of wijst geïrriteerd het voorstel af (o.a. Rains, 2013). Reactance is regelmatig in verband gebracht met psychotherapie (o.a. Schaap et al., 1991; Strong \& Claiborn, 1982; Tennen et al., 1981). Vanwege hun klachten ervaren patiënten vaak een verminderde controle over hun leven. Het is allerminst vanzelfsprekend dat patienten dan openstaan voor een goed bedoeld advies om het nu maar eens over een andere boeg te gooien.

Het 'Elaboration Likelihood Model' (ELM) van Petty en Cacioppo (1986) is een van de eerste en best onderzochte dual processes modellen binnen de psychologie. ELM beschrijft wetmatigheden in sociale beïnvloeding. Volgens ELM verandert sociale beïnvloeding afhankelijk van de mate waarin informatie centraal verwerkt wordt. Als iemand fit en rustig is en een veranderingsvoorstel persoonlijk relevant is en niet in strijd met eigen opvattingen op dat moment, dan is die persoon bereid zich in het voorstel te verdiepen. Als iemand moe is of gespannen, of het voorstel is ingewikkeld met onduidelijke argumenten of met onduidelijke garanties of consequenties, dan laat iemand zich eerder leiden door heuristieken. Het best on- 
derzocht van deze heuristieken zijn waargenomen geloofwaardigheid en betrouwbaarheid en attractiviteit. Het gaat dan om titels, diploma's, passende kleding, ontspannen indruk, fysieke aantrekkelijkheid en gelijkenis wat betreft leeftijd, milieu, opleidingsniveau en interesses (zie o.a. O'Keefe, 2002 voor een overzicht). Bovendien kunnen beide processen, centrale en perifere verwerking, elkaar versterken of afremmen: Een passend geklede voorlichter met een goed beargumenteerd voorstel bereikt extra veel (Petty, Barden, \& Wheeler, 2009). Deze literatuur maakt duidelijk hoe belangrijk het is en hoe nauw het komt om goed aan te sluiten bij iemands visie en beleving om bereidheid tot verandering te verkrijgen.

$\mathrm{Er}$ is fraai experimenteel onderzoek verricht naar 'consistency and commitment'. Een voorstel dat zodanig gebracht wordt dat het aansluit bij wat iemand op dat moment denkt, wordt eerder aangenomen (o.a. Cialdini, 2014; Knowles \& Linn, 2003). Allerlei vormen van erkenning of medewerking, ook al zijn ze klein, vergroten de bereidheid tot verdere investering op de ingeslagen weg (Cialdini, 2014). Die bereidheid dient opgebouwd te worden. Mensen kiezen dan voor zaken waarvoor ze zich eerder uitgesproken hebben. Weerstand tegen verandering neemt af bij een positieve en bevestigende sfeer in het gesprek en bij het uiten van waardering en complimentjes (o.a. Jacks \& O’Brien, 2003). Verder kan weerstand tegen verandering verminderd worden door het weerstandsgedrag te bespreken (Knowles \& Linn, 2003), door verhalen te gebruiken in de plaats van argumenten (o.a. Appel \& Richter, 2007; Dal Cin, Zanna, \& Fong, 2003), door mensen uit te nodigen vooral hun eigen weg te volgen (Quinn \& Wood, 2003) en door mensen aan een gezamenlijke taak met een gezamenlijk doel te laten werken (o.a. Cialdini, 2014).

Vanwege het 'ken uzelf'-ideaal en het geloof in individuele ontplooiing binnen de psychotherapie hebben psychotherapeuten - in termen van wetenschappelijke kennis - veel te weinig door wat ze deden. Wat ze deden was de regels van goede sociale beïnvloeding toepassen. Common factors en het zorgvuldig hanteren van de werkrelatie zijn niks anders als de voortdurende bereidheid creëren en bestendigen dat iemand met behulp van therapeutische technieken met verandering aan de slag gaat. Zonder die bereidheid komt er geen goed therapieresultaat. Common factors en kwaliteit van de werkrelatie dragen niet alleen bij aan het effect van psychotherapie. Ze vormen een essentieel onderdeel van waarom psychotherapie werkt. De psychologische behandelpraktijk houdt veel te veel vast aan naïeve opvattingen dat een goed gesprek helpt om jezelf te vinden. Mijn stelling is dat een beter theoretisch raamwerk moet worden opgezet en dat theorieën daarvoor ontleend kunnen worden aan algemeen geldende principes over sociale beïnvloeding en weerstand tegen verandering Psychotherapie vraagt verandering, verandering roept verzet op. Succesvolle psychotherapie bestaat daarom uit specifieke behandeltechnieken plus een therapeutische context die erop gericht is het vanzelfsprekende verzet te verminderen. Het is goed dat de experimentele klinische psychologie 
verstoorde cognitieve processen identificeert, maar het is ook essentieel om common factors te gaan bestuderen. ${ }^{8}$

\section{De toekomst}

Effectieve psychotherapie nu en in de komende jaren bestaat natuurlijk uit theoretisch en empirisch goed onderbouwde behandeltechnieken. Maar het kan geen kwaad hier aan het einde van mijn betoog nog eens de vraag te stellen wie die technieken uitvoert. Wie verricht het werk? De therapeuten? De ontwerpers van behandelingen? Nee, de patiënten doen het werk. ${ }^{9}$ Meer dan vroeger weten we wat patiënten gericht kunnen doen om van hun klachten af te komen. We hebben nu 110 ESTs en ieder jaar ontwikkelen we nieuwe behandelingen. De patiënt dient echter het werk te doen. Hij dient de behandeling te zien zitten, vertrouwen te hebben dat het gaat lukken, steun te krijgen als het moeilijk is en acceptatie en erkenning voor het moeilijke leven met klachten.

$\mathrm{Nu}$ er minder tijd is binnen de generalistische ggz en we $e$-health gaan inzetten, verwacht ik dat we gaan kiezen voor ESTs, dat wil zeggen voor empirisch gevalideerde klachtspecifieke psychologische behandeltechnieken. Ongetwijfeld gaan huiswerkopdrachten en dagelijkse oefening een groot deel uitmaken van die kortere behandelingen. De uitdaging is echter om

\footnotetext{
${ }^{8}$ 'Common factors' en' werkrelatie' worden in deze tekst vaak in een adem genoemd. Er is weinig consensus over wat de overige common factors precies zijn en hoe ze van de kwaliteit van werkrelatie gescheiden moeten worden. Het gaat om zaken als 'veranderingsbereidheid', 'therapieverwachting' en 'hoop'. In deze rede is niet geprobeerd deze begrippen te ontwarren. Het is wel zinvol hier op te merken dat niet alle common factors gebaseerd zijn op sociale beïnvloeding of weerstand tegen sociale beïnvloeding. Er zijn ook algemene therapiefactoren die verandering bevorderen en weerstand verminderen, maar die meer te maken hebben met intrapersoonlijke leer- en implementatieprincipes (Keijsers et al., 2012, 2013). Hier volgen enkele voorbeelden: Fysieke 'cues' (bijv. een post-it op de bureaulamp om op tijd pauze te nemen) zijn behulpzaam om op het juiste moment aan het juiste gedrag te denken; tactische veranderingen in een situatie (bijv. geen chips meer in huis hebben en etensresten weggooien) helpen om ongewenst automatisch gedrag te voorkómen; realistische doelen stellen, die doelen concreet maken, implementatie-intenties gebruiken, grote stappen in kleine stappen opdelen en een tijdsplanning maken helpen bij het acceptabel en bereikbaar maken van gedragsveranderingen; opwekken van emoties (mits niet te sterk) tijdens gesprekken bevordert associatief leren (Ledoux, 2002). Vooral Hoogduin is een meester in het bedenken van dit soort implementatieprincipes (o.a. Hoogduin, 2011).

${ }^{9}$ Ook wat de bijdrage van patiëntfactoren aan het behandelresultaat betreft, kunnen alleen maar schattingen gegeven worden. Het effect is niet te isoleren van algemene therapeutische context of therapeutische technieken. De 'cirkel van Lambert' veronderstelde dat $40 \%$ van het effect van therapie toegewezen moet worden aan patiëntfactoren en factoren buiten de therapie. Norcross en Lambert (2011) introduceerden een verbeterd model en komen tot een schatting van $30 \%$. Wampold (2001) concludeerde op basis van berekeningen dat $22 \%$ van het behandelresultaat van psychotherapie toegeschreven kan worden aan patiëntfactoren. Met Wampolds correspondentieberekening komt dat neer op een Cohen's $d$ van 1.06. Dat is groot. Predictieonderzoek naar patiëntfactoren (waaronder aard en ernst van klachten, therapiemotivatie, veranderingsbereidheid, verwachtingen, weerstand) maakt aannemelijk dat deze hoge schattingen realistisch zijn. Cooper (2008) bespreekt deze literatuur en merkt op: "Drawing these findings together, it seems reasonable to propose that at the heart of most successful therapies, is a client who's willing and able to become involved in making changes to her or his life." (p. 157).
} 


\section{Old Joke:}

'How many therapists does it take to change a lightbulb?'

'One, but the lightbulb has really got to want to change.'

Figuur 3. Uit Cooper (2008), p. 157.

patiënten bereid te vinden om in de aangeboden behandeling gaan investeren, geïnvolveerd te raken en in korte tijd flink met de oefeningen aan de slag te gaan. Niet voor niets is 'adherentie', het opvolgen van behandeladviezen, het grootste struikelblok bij e-health.

Of kortere behandelingen en e-health succesvol zijn, hangt wederom sterk af van de correctie wijze van aansluiten op de patiënt, hen bewegen in de behandeling te gaan investeren en daarin blijven te investeren zonder hen daarbij onder druk te zetten. Nieuwe mediatechnieken en gebruik van apps kunnen zeer bruikbaar zijn in het ondersteunen van veranderingsprocessen. Online registraties en herhalende boodschappen kunnen bijvoorbeeld op smartphones worden geplaatst. Maar ook dan hebben we communicatietheorie en theorie over beïnvloeding nodig om te begrijpen waarom bijvoorbeeld reminders werken bij gedragsverandering. Graag wil ik op de secties waar ik aangesteld ben, zowel binnen de Radboud Universiteit als de Universiteit Maastricht, onderzoek te verrichten naar common factors binnen de psychotherapie en bij te dragen aan het specificeren van die factoren.

\section{Dankwoord}

Graag gebruik ik dit laatste moment van mijn oratie om mensen te noemen en te bedanken die mijn ambt bij de Universiteit Maastricht hebben mogelijk gemaakt. Daartoe leg ik opnieuw een matrix-model aan $u$ voor.

\section{Dank voor}

\begin{tabular}{|c|c|c|c|c|}
\hline Instantie & $\begin{array}{l}\text { het laatste } \\
\text { jaar }\end{array}$ & $\begin{array}{c}\text { jaren van } \\
\text { collegialiteit }\end{array}$ & $\begin{array}{l}\text { de kunst kunnen } \\
\text { afkijken }\end{array}$ & $\begin{array}{l}\text { common } \\
\text { factors }\end{array}$ \\
\hline $\begin{array}{l}\text { - Faculteit PNS en CPS } \\
\text { Universiteit Maastricht, } \\
\text { RIAGG Maastricht }\end{array}$ & $\begin{array}{l}\text { CvB, Bernadette } \\
\text { Peter, Arnoud }\end{array}$ & & & $\begin{array}{c}\text { Marisol, Sandra } \\
\text { Ina }\end{array}$ \\
\hline - RINO Zuid & $\begin{array}{l}\text { Bestuur, Marrik } \\
\text { collega's }\end{array}$ & & Maaike & Maaike \\
\hline $\begin{array}{l}\text { - Sectie Klinische Psycho- } \\
\text { logie, SPON en NijCare, } \\
\text { Radboud Universiteit }\end{array}$ & & $\begin{array}{l}\text { Alle collega's en de } \\
\text { promovendi Gero, Cara, } \\
\text { Karin, Arno, Gert-Jan, } \\
\text { Wiede, Mirjam, Arno, } \\
\text { Joyce, Caro, Naline, } \\
\text { Aysun en Jorg }\end{array}$ & $\begin{array}{l}\text { Eni, Giel } \\
\text { Cees, Cas } \\
\text { Kees }\end{array}$ & $\begin{array}{l}\text { Agnes } \\
\text { Marc, Gert-Jan } \\
\text { Eni, Wiede } \\
\text { Sanne }\end{array}$ \\
\hline
\end{tabular}




\begin{tabular}{l|l|l|l|l|}
\cline { 2 - 4 } $\begin{array}{l}\text { - Ambulatorium FSW, } \\
\text { Radboud Universiteit }\end{array}$ & Alle collega's & $\begin{array}{c}\text { Kees, Cas } \\
\text { Caro }\end{array}$ & Caro \\
\cline { 2 - 4 } - Thuis & & $\begin{array}{c}\text { Pap, Mam } \\
\text { Lam }\end{array}$ & $\begin{array}{c}\text { Saskia, Miriam } \\
\text { Thomas } \\
\text { Maartje }\end{array}$ \\
\hline
\end{tabular}

Tabel 7: Matrixmodel: Namen.

Ik dank de Universiteit Maastricht in de persoon van Bernadette Jansma, de Decaan van Faculty of Psychology and Neuroscience voor het instellen van mijn leerstoel. Ik voel me welkom op de afdeling Clinical Psychological Science. Er heerst een vriendelijke sfeer en er wordt keihard gewerkt. Sandra, wat doe je veel. Marisol, ik verheug me op de studies die we aan het opzetten zijn. Als ik naar Maastricht afreis is het aangenaam om jou aan het einde van die reis aan te treffen. Ik dank de RIAGG Maastricht in de persoon van Ina Leeuw voor de mogelijkheden voor onderzoek. Arnoud Arntz en Peter Muris, dank voor de coachende gesprekken en het mee helpen zoeken hoe ik mijn rol binnen Clinical Psychological Science gestalte kan geven.

Zeer hartelijk dank ik het bestuur van RINO Zuid en de voorzitter, Piet Verbraak, voor de initiatie en realisatie van de leerstoel. RINO Zuid is ondergebracht in een voormalige kerk, een licht en open gebouw. Veel wanden zijn van glas. Die openheid staat ook voor de open communicatie en elkaar vinden binnen RINO Zuid. Openheid geldt ook voor Marrik van Rozendaal. Dank je Marrik. Zorgvuldig overleg is beslist ook kenmerkend voor Maaike van der Loon. Maaike, je bent recht door zee en je laat zelden steken vallen. Dat je ook gevoelig bent hou je natuurlijk zoveel mogelijk geheim, maar ja, ik ben niet voor niks klinisch psycholoog.

In 1982 begon ik mijn studie psychologie aan de Radboud Universiteit en ik ben daar eigenlijk nooit meer weggegaan. Er zijn veel mensen met wie ik samengewerkt heb, te veel om op te noemen. In de tabel staan mijn promovendi bij naam. Ik beleef en beleefde veel plezier aan elk van deze promotietrajecten en ik ben trots op wat we samen hebben neergezet. Eni Becker, hoofd van de Sectie Klinische Psychologie en het onderzoeksprogramma Experimental Psychology and Treatment, je bent een bijzondere vrouw, slim en een voorbeeld van een goed manager van eigenwijze stand-alone onderzoekers. Cees van der Staak, je hebt de sectie binnengeleid in een tijdperk waarin het sectie-onderzoek een duidelijke focus moest krijgen en je had een grote bijdrage aan de inrichting van het postinitiële psychologieonderwijs. Je bent mij en vele andere tot steun geweest. Giel Hutschemaekers, ik dank je voor je vriendschap, je steekt je handen uit de mouwen en je bent een virtuoos denker. Agnes van Minnen, Marc Verbraak en Gert-Jan Hendriks, we trokken samen op als leerlingen van Kees Hoogduin. Ons bindt plezier in het doen van onderzoek en bijdragen aan het welzijn van patienten. Agnes, ik dank je voor de jarenlange vriendschap en alle samenwerking. Je bent een boegbeeld geworden in het internationale PTSS-onderzoek en je bent ook een boegbeeld in 
mijn leven. Wiede Vissers, Wiede, dank je voor de spiegel die je me zo nu en dan voorhoudt. Ik neem je niet meer achterop de fiets als ik een glas wijn teveel heb gedronken.

Ik ben vijf jaar hoofdopleider KP geweest bij SPON. Monique Schijvenaars, dank je voor de zorgvuldigheid als SPON-directeur. Sanne Weller, dat hoofdopleiderschap moest ik van iemand leren, Sanne. Wij deden het goed samen. En met heel veel plezier. Dank je voor je zorgvuldigheid, je inzet en je vriendschap.

Cas Schaap en Kees Hoogduin waren mijn promotors en hebben mij op het pad gezet van onderzoek en behandeling. Cas, ik hoop van harte dat je jouw stempel hebt herkend in de oratie die ik vandaag heb uitgesproken. Kees, je hebt de psychotherapie in Nederland veranderd en niet alleen mij, maar een hele schare anderen diepgaand beïnvloed. Wij, jouw leerlingen, grinniken nog regelmatig als we elkaar betrappen op het gebruiken van typische uitdrukkingen van jou. Ik dank je voor alles wat je voor mij mogelijk hebt gemaakt.

Het Ambulatorium FSW is een kleine psychotherapiepraktijk waar patiëntgebonden onderzoek en behandelingen plaatsvinden. Ik dank iedereen met wie ik daar werk en met name wil ik Caroline Vossen noemen. Caro, je bent sterk betrokken op alles wat op het Ambulatorium gebeurt. Wij hebben een lange geschiedenis van leren van elkaar, gezamenlijk verantwoordelijkheden dragen en vriendschap.

Pap en man, wat fijn dat jullie hier zijn. Maar eigenlijk ook geen wonder omdat jullie aanwezig zijn bij alle stappen in mijn leven en in het leven van jullie kinderen en kleinkinderen. Lam, mijn tweelingbroer en eveneens klinisch psycholoog, we passen de dezelfde jas, we houden van dezelfde muziek en we hebben hetzelfde loopje. Ik kan er niks aan doen, maar jij staat hier ook een beetje. Saskia, Miriam en Thomas ik durf jullie niet zo goed aan te kijken, want dan breekt mijn stem misschien een beetje. Als aan tafel thuis iedereen om beurten vertelt wat het leukste is wat hij of zij vandaag heeft meegemaakt, en als jullie dan zitten te kwetteren, dan voel ik me zo rijk. En jij, jij staat achteraan, mijn mooie lieve vrouw. Ik kan je bedanken voor kleine dingen, zorgen dat er op tijd cadeautjes zijn, dat de auto vol getankt is, of dat het boodschappenlijstje is gemaakt, maar ik weet niet of ik je kan bedanken voor de grote dingen, anders dan je te zeggen hoe zielsgelukkig ik met je ben.

\section{Ik heb gezegd.}

\section{Referentielijst}

Appel, M., \& Richter, T. (2007). Persuasive effects of fictional narrative increase over time. Media Psychology, 10, 113-135.

Bakker, R., Melsen, A.G.M. van, \& Peursen, C.A. van, (1985). Inleiding tot de wijsbegeerte in christelijk perspectief. Kampen: Uitgeversmaatschappij J.H. Kok Kampen.

Barlow, D.H., (2007). Psychotherapy and psychological treatments: The future. Clinical Psychology: Science and Practice, 13, 216-220. 
Bögels, S.M., \& Mansell, W. (2004). Attention processes in the maintenance and treatment of social phobia: Hypervigilance, avoidance, and self-focused attention. Clinical Psychology Review, 24, 827-856.

Bøgwald, K.J. (2001) Do patients and their therapists agree on the content of treatments. Journal of Nervous and Mental Disease, 189, 830-837.

Bohart, A.C., Elliott, R., Greenberg, L.S., \& Watson, J.C. (2002). Empathy. In J.C. Norcross (Ed.), Psychotherapy relationships that work: Therapist contributions and responsiveness to patients (pp. 89-108). New York: Oxford University Press.

Bouman, T., Visser, S., \& Vervaeke, G. (2011). Protocollaire behandeling van patiënten met hypochondrie. In G.P.J. Keijsers, A. Van Minnen and C.A.L. Hoogduin (Eds.), Protocollaire behandelingen voor volwassenen met psychische problemen 2 (pp. 49-84). Amsterdam: Boom.

Carr, A. (1987). The easy way to stop smoking. Harmondsworth: Penguin.

Carr, A. (2009). What works with children, adolescents, and adults? A review of research on the effectiveness of psychotherapy. East Sussex: Routledge.

Chambless, D.L., \& Ollendick, T.H. (2001). Empirically supported psychological interventions: Controversies and evidence. Annual Review of Psychology, 52, 685-716.

Cialdini, R.B. (2014). Influence: Science and practice (5 $5^{\text {th }}$ ed.). Harlow, Essex: Pearson.

Colijn, S., Snijders, H., \& Trijsburg, W. (2009). Universele psychotherapiefactoren. In S. Colijn, H. Snijders, M. Thunnissen, S. Bögels and W. Trijsburg (Eds.), Leerboek psychotherapie (pp. 159-168). Utrecht: De Tijdstroom.

Cooper, M. (2008). Essential research findings in counseling and psychotherapy. Los Angeles, BACP.

Craighead, W., Shets, E., Brosse, A., \& Ilardi, S. (2007). Psychosocial treatments for major depressive disorder. In P. Nathan and J. Gorman (Eds.), A guide to treatments that work (3rd ed., pp. 289-308). New York: Oxford University Press.

Craske, M.G., Kircanski, K., Zelikowsky, M., Mystkowski, J., Chowdhury, N., \& Baker, A. (2008). Optimizing inhibitory learning during exposure therapy. Behaviour Research and Therapy, 46, 5-27.

Crits-Christoph, P. (1997). Limitations of the Dodo bird verdict and the role of clinical trials in psychotherapy research: Comment on Wampold et al. (1997). Psychological Bulletin, 122, 216-220.

Dal Sin, S., Zanna, M.P., \& Fong, G.T. (2008). Narrative persuasion and overcoming resistance. In E.S. Knowles and J.A. Linn (Eds.), Resistance and persuasion (pp. 175-191). Mahwah, New Jersey: Lawrence Erlbaum.

DeRubeis, R. J., Brotman, M. A., \& Gibbons, C. J. (2005). A conceptual and methodological analysis of the nonspecifics argument. Clinical Psychology: Science and Practice, 12, 174-183.

Eberl, C., Wiers, R.W., Pawelczack, S., Rinck, M., Becker, E.S., \& Lindenmeyer, J. (2013). Approach bias modification in alcohol dependence: Do clinical effects replicate and for whom does it work best? Developmental Cognitive Neuroscience, 4, 38-51.

Elliott, R., Bohart, A.C., Watson, J.C., \& Greenberg, L.S. (2011). Empathy. In J.C. Norcross (Ed.), Psychotherapy relationships that work: Evidence-based responsiveness $\left(2^{\text {nd }}\right.$ ed., pp. 132-152). New York: Oxford University Press.

Emmelkamp, P.M.G. et al. (2014). Advancing psychotherapy and evidence-based psychological interventions. International Journal of Methods in Psychiatric Research, 23, suppl. 1, 58-91.

Fisher, J.E., \& O’Donohue, W.T. (2006). Practioner's guide to evidence-based psychotherapy. New York: Springer.

Garfield, S.L., \& Bergin, A.E. (1986). Introduction and historical overview. In S.L. Garfield and A.E. Bergin (Eds.), Handbook of psychotherapy and behavior change (3 ${ }^{\text {rd }}$ ed., pp. 3- 22). New York: Wiley. 
Hallion, L.S; \& Ruscio, A. M. (2011). A meta-analysis of the effects of cognitive bias modification in anxiety and depression. Psychological Bulletin, 137, 940-958.

Harvey, A., Watkins, E., Mansell, W., \& Shafran, R. (2006). Cognitive behavioural processes across psychological disorders: A transdiagnostic approach to research and treatment. Oxford: University Press.

Hofman, S. G. (2008). Cognitive processes during fear acquisition and extinction in animals and humans: Implications for exposure therapy and anxiety disorders. Clinical Psychology Review, 28, 199-210.

Hoogduin, C.A.L. (2011). Behandeling met behulp van zelfcontroleprocedures. In K. van der Velden, C.A.L. Hoogduin and A. Lange (Eds.), Directieve therapie (pp. 139-158). Amsterdam: Boom.

Horvath, A.O., \& Bedi, R.P. (2002). The alliance. In J.C. Norcross (Ed.), Psychotherapy relationships that work: Therapist contributions and responsiveness to patients (pp. 37-70). New York: Oxford University Press.

Horvath, A.O., \& Symonds, B.D. (1991). Relation between working alliance and outcome in psychotherapy: A meta-analysis. Journal of Counseling Psychology, 38, 139-149.

Horvath, A.O., Flückiger, C., \& Symonds, A. (2011). Alliance in individual psychotherapy. In J.C. Norcross (Ed.), Psychotherapy relationships that work: Evidence-based responsiveness ( $2^{\text {nd }}$ ed., pp. 25-69). New York: Oxford University Press.

Howard, K.I., Krause, M.S., Saunders, S.M., \& Kopta, S.M. (1997). Trials and tribulations in the meta-analysis of treatment differences: Comment on Wampold et al. (1997). Psychological Bulletin, 122, 221-225.

Hunsley, J., \& Di Giulio, G. (2002). Dodo bird, phoenix, or urban legend? The question of psychotherapy equivalence. The Scientific Review of Mental Health Practice: Objective Investigations of Controversial and Unorthodox Claims in Clinical Psychology, Psychiatry, and Social Work, 1, 11-22.

Jacks, J.Z., \& O'Brien, M.E. (2003). Decreasing resistance by affirming the self. In E.S. Knowles and J.A. Linn (Eds.), Resistance and persuasion (pp. 235-257). Mahwah, New Jersey: Lawrence Erlbaum.

Kampman, M., Keijsers, G.P.J., \& Hendriks, G.-J. (2011). Protocollaire behandeling van patiënten met een paniekstoornis met of zonder agorafobie: interoceptieve exposure, cognitieve gedragstherapie en exposure in vivo. In G.P.J. Keijsers, A. Van Minnen and C.A.L. Hoogduin (Eds.), Protocollaire behandelingen voor volwassenen met psychische problemen 1 (pp. 37-77). Amsterdam: Boom.

Kazdin, A.E., \& Bass, D. (1989). Power to detect differences between alternative treatments in comparative psychotherapy outcome research. Journal of Consulting and Clinical Psychology, 57, 138-147.

Keijsers, G.P.J., \& Becker, E.S. (2009). Succesvolle psychotherapie: Praten, maar vooral ook oefenen. MGv, 64, 148-155.

Keijsers, G.P.J., Minnen, A. van, \& Hoogduin, C.A.L. (2006). Kunnen ongewenste gewoonten blijvend veranderd worden? Zelfcontrole in de klinische psychologie. De Psycholoog, 41, 594-600.

Keijsers, G.P.J., Minnen, A. van, \& Hoogduin, C.A.L. (2011). Toepassing van protocollaire behandelingen bij psychische stoornissen. In G.P.J. Keijsers, A. Van Minnen and C.A.L. Hoogduin (Eds.), Protocollaire behandelingen voor volwassenen met psychische problemen 1 (pp. 13-34). Amsterdam: Boom.

Keijsers, G.P.J., Schaap, C.P.D.R., \& C.A.L. Hoogduin (2000). The impact of interpersonal patient and therapist behaviour on outcome in cognitive-behavior therapy: A review of empirical studies. Behavior Modification, 24, 264-297.

Keijsers, G.P.J., Schaap, C.P.D.R., Hoogduin, C.A.L., Hoogsteyns, B., \& Kemp, E.C.M., de. (1999). Preliminary results on a new instrument to assess patient motivation for treatment in cognitive-behaviour therapy. Behavioural and Cognitive Psychotherapy, 27, 165-179.

Keijsers, G.P.J., Vissers, W., Hutschemaekers, G.J.M., \& Witteman, C.L.M. (2010). Empirisch ondersteunde psychologische behandelingen. Moeten we dat nu wel doen? MGV-maandblad geestelijke volksgezondheid, 65, 364-377. 
Keijsers, G.P.J., Vossen, C.J.C., \& Keijsers, L.H.A. (2012). Helpen veranderen: Motiveringsstrategieën in de ambulante psychotherapie. Amsterdam: Boom.

Keijsers, G.P.J., Vossen, C.J.C., \& Keijsers, L.H.A. (2013). Patiënten motiveren tot het uitvoeren van protocollaire behandelingen. In P.G.M. Emmelkamp and C.A.L. Hoogduin (Eds.), Van mislukking naar succes in de psychotherapie (pp. 23-46). Amsterdam: Boom.

Keijsers, G.P.J., Woud, M.L., \& Becker, E.S. (2009). Impliciete mentale processen. In S. Colijn, H. Snijders, M. Thunnissen, S. Bögels, \& W. Trijsburg (Eds.), Leerboek psychotherapie (pp. 255-263). Utrecht: De Tijdstroom.

Knowles, E.S., \& Linn, J.A. (2003). Approach-avoidance model of persuasion: Alpha and omega strategies for change. In E.S. Knowles and J.A. Linn (Eds.), Resistance and persuasion (pp. 117-148). Mahwah, New Jersey: Lawrence Erlbaum.

Lambert, M.J. (1992). Psychotherapy outcome research: Implications for integrative and eclectic therapists. In J.C. Norcross and M.R. Goldfried (Eds.), Handbook of psychotherapy integration (pp. 94-129). New York Basic Books.

Lambert, M.J., Shapiro, D.A., \& Bergin, A.E. (1986). The effectiveness of psychotherapy. In S.L. Garfield and A.E. Bergin (Eds.), Handbook of psychotherapy and behavior change ( $3^{\text {rd }}$ ed., pp. 157- 212). New York: Wiley.

LeDoux, J.E. (2002). Synaptic self: How our brains become who we are. New York: Pinguin Books.

MacLeod, C., \& Mathews, A. (2012). Cognitive bias modification approaches to anxiety. Annual review of Clinical Psychology, 8, 189-217.

Mahoney, M.J. (1991). Human change processes: The scientific foundations of psychotherapy. New York: BasicBooks.

Martin, D.J., Garske, J.P., \& Davis, K.M. (2000). Relation of the therapeutic alliance with outcome and other variables: A meta-analytic review. Journal of Clinical and Consulting Psychology, 68, 438-450.

Meier, P.S., \& Donmall, M.C. (2005). Differences in client and therapist views of the working alliance in drug treatment. Journal of Substance Use, 11, 73-80.

Miller, W.R., Wilbourne, P.I., \& Hettema, J. (2003). What works? A summary of alcohol treatment outcome research. In R.K. Hester and W.R. Miller (Eds.), Handbook of alcoholism treatment approaches: Effective alternatives ( $3^{\text {rd }}$ ed., pp. 13-63). Boston: Allyn \& Bacon.

Minnen, A., van \& Arntz, A. (2011). Protocollaire behandeling van patiënten met een posttraumatische stressstoornis. In G.P.J. Keijsers, A. van Minnen, and C.A.L. Hoogduin (Eds.), Protocollaire behandelingen voor volwassenen met psychische problemen 1 (pp. 181-212). Amsterdam: Boom.

Minnen, A. van, Hoogduin, C.A.L., Keijsers, G.P.J., Hellenbrand, I., \& Hendriks, G.-J. (2003). Treatment of trichotillomania by behavior therapy or fluoxetine: A randomized, waiting-list controlled study. Archives of General Psychiatry, 60, 517-522.

Neziroglu, F., \& Santos, N.M. (2013). Advances in the treatment of body dysmophic disorder. International Journal of Cognitive Therapies, 6, 138-149.

Norcross, J.C., \& Lambert, M.J. (2011). Evidence-based therapy relationships. In J.C. Norcross (Ed.), Psychotherapy relationships that work: Evidence-based responsiveness $\left(2^{\text {nd }}\right.$ ed., pp. 3-21). New York: Oxford University Press.

O'Keefe, D.J. (2002). Persuasion: Theory and research (2 $2^{\text {nd }}$ ed.). Thousand Oakes: Sage Publications.

Ollendick, T.H., \& King, N.J. (2006). Empirically supported treatments typically produce outcomes superior to non-empirically supported treatment therapies. In J.C. Norcross, L.E. Beutler, \& R.F. Levant (Eds.), Evidence-based practices in mental health: Debate and dialogue on the fundamental questions (pp. 308-317, 319-328). Washington, D.C.: American Psychological Association. 
Petty, R.E., Barden, J., \& Wheeler, S.C. (2009). The elaboration likelihood model of persuasion: Developing health promotion for sustained behavior change. In R.J. DiClemente, R.A. Crosby, and M. Kegler (Eds.), Emerging theories in health promotion in practice and research $\left(2^{\text {nd }} e d, p p .185-214\right)$. San Francisco: Jossey-Bass Public Health.

Petty, R.E., \& Cacioppo, J.T. (1986). The elaboration likelihood model of persuasion. In L. Berkowitz (Ed.), Advances in experimental social psychology volume 19 (pp. 123-205). New York: Academic Press.

Prochaska, J.O., DiClimente, C.C., \& Norcross, J.C. (1992). In search of how people change. American Psychologist, 47, 1102-1114.

Quinn, J.M. \& Wood, W. (2003). Forewarning of influence appeals: Inducing resistance and acceptance. In E.S. Knowles and J.A. Linn (Eds.), Resistance and persuasion (pp. 193-214). Mahwah, New Jersey: Lawrence Erlbaum.

Rains, S.A. (2013). The nature of psychological reactance revisited: A meta-analytic review. Human Communication Research, 39, 47-73.

Rosenthal, R., Rosnow, R.L., \& Rubin, D.B. (2000). Contrasts and effect sizes in behavioral research: A correlational approach. Cambridge: Cambridge University Press.

Roth A., \& Fonagy, P. (2005). What works for whom? A critical review of psychotherapy research (2 ${ }^{\text {nd }}$ ed.). London: Guilford Press.

Sectorrapport ggz (2010). Zorg op waarde geschat. Update. Amersfoort: GGZ-Nederland.

Schaap, C., Bennun, I., Schindler, L., \& Hoogduin, K. (1993). The therapeutic relationship in behavioural psychotherapy. Chichester: Wiley.

Schippers, G. , \& Kampman, M. (1999). Motivatie: Wat we van verslaafden kunnen leren. In C.P.F. Van der Staak., G.P.J. Keijsers, and C.A.L. Hoogduin (Eds.), Motivering voor gedragsverandering (pp. 72-88). Houten: Bohn Stafeu Van Loghum.

Schmidt, N.B., \& Keough, M.G. (2010). Treatment of panic. Annual Review of Clinical Psychiatry, 6, 241-256.

Smeets, E., Jansen, A., \& Roefs, A. (2011). Bias for the (un)attractive self: On the role of attention in causing body (dis)satisfaction. Health Psychology, 30, 360-367.

Strong, S.R., \& Claiborn, C.D. (1982). Change through interaction: Social psychological processes of counseling and psychotherapy. New York: Wiley.

Tennen, H., Rohrbach, M., Press, S., \& White, L (1981). Reactance theory and therapeutic paradox: A compliance- defiance model. Psychotherapy, 18, 14-21.

Veerbeek, M., Knispel, A., \& Nuijen, J. (2012). GGZ in tabellen 2011. Utrecht: Trimos-instituut.

Verbraak, M.J.P.M., Hoogduin, C.A.L., \& Keijsers, G.P.J. (2011). Protocollaire behandeling van patiënten met een obsessieve-compulsieve stoornis. In G.P.J. Keijsers, A. Van Minnen and C.A.L. Hoogduin (Eds.), Protocollaire behandelingen voor volwassenen met psychische problemen 1 (pp. 79-110). Amsterdam: Boom.

Verdellen, C.W.J., Keijsers, G.P.J., Hoogduin, C.A.L., \& Cath, D.C. (2004). Exposure with response prevention versus habit reversal in Tourette's syndrome: A controlled study. Behaviour Research and Therapy, 42, 501-512.

Wampold, B.E. (2001). The great psychotherapy debate: Models, methods, and findings. Hawah, New Jersey: Lawrence Erlbaum Associates.

Wampold, B.E., Mondin, G.W., Moody, M., Stich, F., Benson, K., \&Ahn, H. (1997). A meta-analysis of outcome studies comparing bona fide psychotherapies. Empirically "All must have prizes." Psychological Bulletin, $122,203-2015$. 
Wildt, W. de, Merkx, M., Vedel, E., \& Schippers, G. (2011). Protocollaire behandeling van patiënten met een stoornis in het gebruik van alcohol. In G.P.J. Keijsers, A. Van Minnen and C.A.L. Hoogduin (Eds.), Protocollaire behandelingen voor volwassenen met psychische problemen 1 (pp. 381-406). Amsterdam: Boom.

Wilson, T.D., \& Dunn, E.W. (2004). Self-knowledge: Its limits, value, and potential for improvement. Annual Review of Psychology, 55, 493-518.

Yperen, T. van, Steege, M., van der, Addink, A., \& Boendermacher, L. (2010). Algemeen en specifiek werkzame factoren in de jeugdzorg: Stand van de discussie (rev.). Utrecht: Nederlands Jeugdinstituut. 